\title{
PEMBINAAN KEPEDULIAN PESERTA DIDIK PADA LINGKUNGAN SEKOLAH DENGAN MEMBERIKAN PELATIHAN MENANAM HIDROPONIK TEKNIK VERTICAL
}

\section{BUILDING OF STUDENTS CARE IN SCHOOL ENVIRONMENT BY HYDROPONIC PLANTING TRAINING USING VERTICAL TECHNIQUES}

\author{
Deni Nasir Ahmad \\ Fakultas Teknik Matematika dan Ilmu Pengetahuan Alam. Universitas Indraprasta PGRI \\ Jl. Nangka No.58 C. Tanjung Barat, Jagakarsa. Jakarta Selatan \\ Telp. (021) 78835283, 7818718. Fax : (021) 29121071 \\ Email : deninasirahmad@gmail.com
}

Diterima: 12 Desember 2017. Disetujui: 28 Maret 2018. Dipublikasikan: 31 Maret 2018

\begin{abstract}
Abstrak: Telah dilakukan kegiatan pengabdian masyarakat berupa pelatihan penanaman tanaman hidroponik dengan teknik vertical garden di SMPN 1 Cijeruk, Bogor, Jawa Barat. Tujuan kegiatan ini adalah memberikan penyuluhan ke peserta didik betapa pentingnya keasrian, kenyamanan dan keindahan pada lingkungan sekolah. Kedua, memberikan pengetahuan dan keterampilan kepada peserta didik untuk membuat teknologi hidroponik dengan teknik "vertical garden". Tujuan selanjutnya adalah memberikan alat peraga tekhnologi hirdoponik teknik "vertical garden" ke sekolah sebagai media pembelajaran cinta dan perduli lingkungan. Hasil dari kegiatan tersebut adalah tim pengabdian masyarakat mampu menumbuhkan antusiasme peserta didik dalam menerima materi dan pelatihan. Kedua, peserta didik dan guru sekolah memiliki pengetahuan baru tentang teknologi rekayasa vertikal. Ketiga, pengetahuan yang didapat dapat dimanfaatkan sebagai sarana belajar dan membuat lingkungan sekolah menjadi indah dan nyaman dalam kegiatan pembelajaran. Keempat, pemberian alat praga kepada sekolah sebagai hasil dari kegiatan pelatihan. Kesimpulan bahwa pelatihan tanam hidroponik mampu menanamkan sifat peduli lingkungan dari peserta didik.
\end{abstract}

Kata Kunci : peduli lingkungan, hidroponik, vertical garden

\begin{abstract}
Community service activities have been conducted through hydroponic planting training at SMPN 1 Cijeruk, Bogor, Jawa Barat. The purpose of this activity is to provide counseling to learners how important comfort and beauty in the school environment. Second, to provide knowledge and skills to learners to create hydroponic technology with the technique of "vertical garden". The next goal is to provide a tool of hydroponic technology to the school as a learning medium for environmental care. The result of the activity is the community service team is able to foster the enthusiasm of learners in receiving materials and training from the team of dedication. Second, learners and school teachers have new knowledge of vertical engineering technology. Third, the knowledge gained can be utilized as a means of learning and make the school environment to be beautiful and comfortable in learning activities. Fourth, the provision of tools and media outcomes of training activities to schools. The conclusion that hydroponic planting training is able to inculcate the environment-caring nature of the learners
\end{abstract}

Keywords: environmental care, hydroponics, vertical garden

\section{PENDAHULUAN}

Kepedulian lingkungan adalah suatu keadaan psikologis berupa perhatian, kesadaran, dan tanggungjawab terhadap kondisi pengelolaan lingkungan [1-3]. Menurut Kemendiknas sikap kepedulian lingkungan adalah sikap dan tindakan yang selalu berupaya mencegah kerusakan pada lingkungan alam disekitarnya, dan mengembangkan upaya-upaya untuk memperbaiki kerusakan alam yang sudah terjadi [4]. Oleh karenanya penanaman kepedulian terhadap lingkungan perlu dilakukan untuk memberikan tingkat kesadaran peserta didik terhadap lingkungannya terutama lingkungan sekolah dan tempat tinggalnya. Pengelolaan lingkungan hidup bisa melalui perbaikan kerusakan lingkungan berupa penanaaman, pemanfaatan sumber energi alternatif ramah lingkungan dan lain-lain.

Pemanfaatan sumber daya alam dalam kehidupan sehari-hari demi untuk kesejahteraan umat manusia tidak dibarengi dengan pengelolaan dan penggunaan kembali sumber daya alam yang telah terbuang misalkan adanya sampah plastik, adanya sampah organik dan lain-lain. Oleh karena itu pemanfaatan sumber daya alam harus dibarengi dengan cara memperbaiki kerusakan yang ada dialam. Sampah plastik sangatlah susah diuraikan oleh bakteri tanah mengakibatkan terjadinya pencemaran pada tanah. Pencemaran pada tanah ini menyebabkan tingkat kesuburan tanah menjadi berkurang. 
Oleh sebab itu maka perlu dilakukan tindakan yaitu dengan cara 3R (Reuse, Reduce dan Recycle). Penggunaan botol plastik sebagai wadah media tanam bisa dipergunakan dalam penggunaan tanaman hidroponik teknik tanam vertikal atau vertical garden. Hidroponik istilah yang digunakan untuk menjelaskan cara bercocok tanam tanpa tanah tetapi menggunakan air atau bahan porous lainnya dengan pemberian unsur hara terkendali yang berisi unsur-unsur esensial yang dibutuhkan tanaman $[4,5]$. Vertical garden dikenal juga dengan nama green wall, living wall maupun bio wall yang merujuk pada tanaman yang dapat tumbuh secara langsung pada fasade bangunan maupun tanaman yang tumbuh pada sistem struktur yang terpisah sehingga dapat diberdirikan atau ditempelkan pada dinding [6,7]. Manfaat dari penanaman dengan teknik vertical garden yakni dapat menurunkan suhu ruangan dan suhu diluar ruangan. Keberadaan vertical garden mampu menurunkan profil suhu permukaan dinding pada bagian lain dalam satu area yang non vertical garden [8,9].

\section{METODE PELAKSANAAN}

Dalam melakukan kegiatan pengabdian masyarakat kami tim pengabdi melakukan langkah kegiatan sebagai berikut: a. memberikan materi pembuatan tanaman hidroponik teknik vertical garden dengan menggunakan botol plastik bekas. b. melakukan pelatihan dengan memberikan contoh dan mempraktekan penanaman teknik vertical garden menggunakan tanaman hidroponik kepada peserta didik. c. diskusi informatif dan tanya jawab yang berkaitan dengan kegiatan yang telah dilakukan. Menurut Roidah[5] pembuatan dan penanaman hidroponik sangat mudah, yaitu : (1) Hal pertama kali dilakukan sebelum membuat bak-bak yang akan dijadikannya sebagai media tanam sayuran, maka terlebih dahulu dilakukan pembersihan lahan untuk lokasi penempatan bak. Media hidroponik ini dapat juga menggunakan bak-bak atau pipa bekas. (2) Jika menggunakan pipa, maka pipa tersebut harus disambung-sambung hingga berbeda pola yang mana dari pola tersebut nantinya dapat berdiri tegak. Sebagai tempat untuk memasukkan benih, dibagian atas pipa yakni yang nantinya menjadi tempat tumbuhnya benih harus dilubangi dengan diameter sekitar $4 \mathrm{~cm}$. pipa-pipa yang saling tersambung tersebut di bagian ujung paling bawah diarahkan ke dalam bak penampung air yang berlebih. (3) Kemudian jika menggunakan media bak, bahanbahan yang digunakan bisa jadi akan lebih murah dibandingkan dengan menggunakan media pipa. Bahan-bahan yang digunakan antara lain bamboo, papan, terpal, plastik, styrofoam. Bahan-bahan tersebut dapat dibeli dengan harga yang sangat murah. Yang dilakukan pertama kali untuk membuat bak tersebut diantaranya dengan membuatnya sebagaimana bak pada umumnya. Setelah selesai dibuat bak, terpal dibentangkan agar dapat menampung air. Tetapi di cek terlebih dahulu terpal yang sudah terpasang dan dilihat ada kebocoran atau tidak. (4) Setelah bak terisi air yang mana kedalamannya tidak melebihi ketebalan Styrofoam. Styrofoam yang sudah tersedia dimasukkan ke dalam bak, sebelum styrofoam tersebut dimasukkan ke dalam bak harus dilubangi terlebih dahulu dengan ukuran diameter sekitar $4 \mathrm{~cm}$. Lubang-lubang tersebut berguna sebagai tempat untuk meletakkan benih sayuran atau buah yang akan ditanam. Pada dasarnya, styrofoam tersebut berfungsi sebagai pengganti media tanah.(5) Selanjutnya untuk melindungi benih agar tidak terkena cahaya matahari secara langsung atau hujan yang bisa merusak benih yang masih halus,sehingga harus dipasang peneduh yang dibuat dari plastik. Peneduh plastik tersebut dibuat secara melengkung agar air hujan tidak ada yang tempias. (6) Dalam beberapa hari, benih yang ditempatkan di dalam styrofoam tersebut mulai tumbuh. Sebagaimana umumnya tanaman sayuran, bisa dipanen setelah berusia 40 hari. Selama berkembang, akar tanaman akan mencari air yang meresap disyterofoam.(7) Styrofoam tersebut nantinya bisa digunakan untuk bertanam sayuran selama berkali-kali.

\section{HASIL DAN PEMBAHASAN}

Upaya menciptakan lingkungan sekolah yang asri dan nyaman dalam belajar dibutuhkan wilayah penghijauan salah satunya penanaman hidroponik teknik vertikal. Penanaman hidroponik teknik vertikal ini di rasa lebih baik dikarenakan penanaman tidak membutuhkan lahan yang luas. Oleh karenanya pemberian materi hidroponik teknik vertikal dan pendaur ulangan sampah botol plastik menjadi fokus utama dalam pemberian materi. Dengan kegiatannya ini diharapkan para peserta didik memahami betapa pentingnya membuat lingkungan sekolah asri dan nyaman agar peserta didik mempunyai sikap cinta dan menyayangi lingkungan. Terutama lingkungan di tempat tinggal mereka sendiri. Adapun kegiatan yang kami lakukan adalah: a. Pemberian materi diberikan oleh tim pengabdi (dosen pembina dan mahasiswa) kepada peserta didik. Dalam kegiatan pengabdian ini membuat mahasiswa-mahasiswi jurusan pendidikan tidak lagi mengalami kebingungan dalam mengajarkan peserta didik setelah lulus dari pendidikan mereka. Umpan balik peserta didik pun memperoleh pengetahuan baru dalam teknologi pertanian. b. Setelah melakukan presentasi para peserta didik diajarkan cara penanaman hidroponik teknik vertikal dengan menggunakan botol plastik sebagai media tanam oleh para tim pengabdi. c. Diskusi Interaktif antara Tim pengabdi dengan peserta didik. Peserta didik yang mampu menjawab dan aktif dalam kegiatan maka diberikan kenangkenangan agar peserta didik dapat terus semangat menciptakan lingkungan sekolah yang asri dan nyaman. Gambar 1 menunjukkan hasil dari kegiatan dan penempatan lahan disediakan sekolah. 


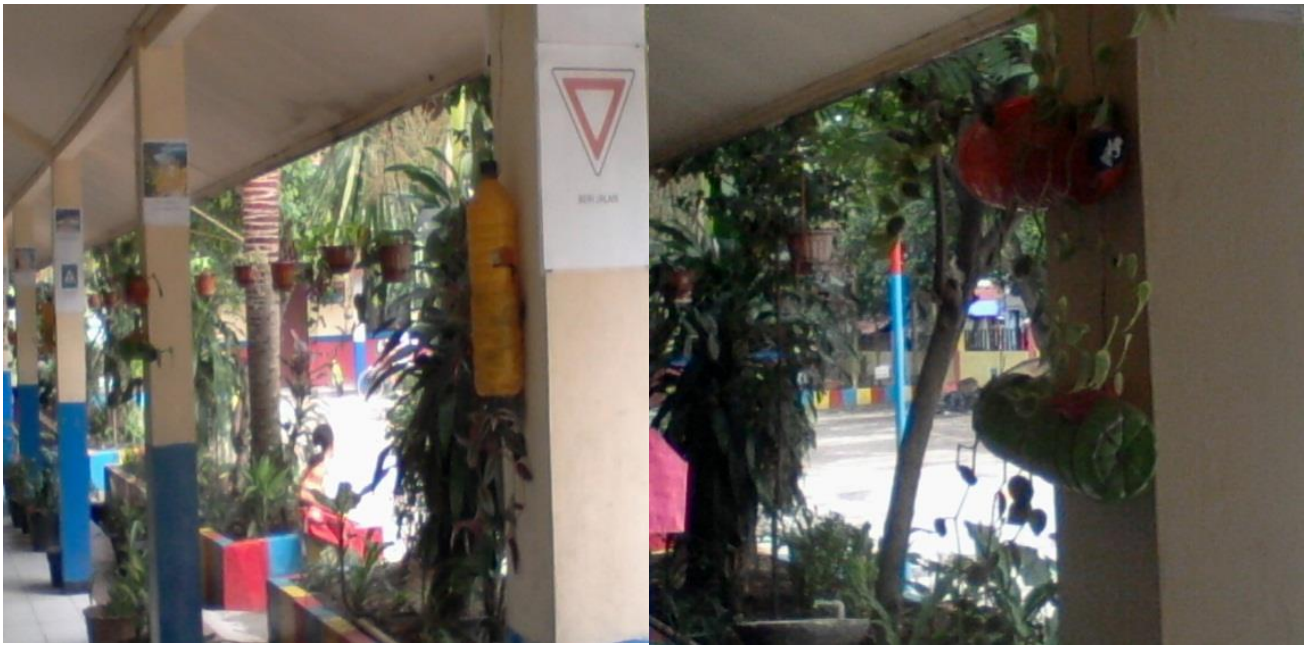

Gambar : Hasil Kegiatan Pelatihan penanaman tanaman hidroponik dengan teknik vertical garden.

Adapun hasil dari kegiatan pengabdian masyarakat yang telah kami lakukan adalah sebagai berikut: 1 . Pengabdi memperoleh rasa puas dan bangga terhadap peserta didik yang telah bekerjasama menerima materi dan pelatihan dari tim pengabdi terlihat dari peserta didik banyak berantusias dalam kegiatan. 2 . Peserta didik dan sekolah yang kami kunjungi sebagai mitra pengabdi memiliki rasa puas dikarenakan peserta didik diberikan pengetahuan baru teknologi pertanian teknik vertikal. 3. Tim pengabdi sangat berharap agar ilmu yang diberikan dapat digunakan sebagai sarana pembelajaran dan membuat lingkungan sekolah menjadi asri dan nyaman dalam kegiatan pembelajarannya. 4. Tim Pengabdi memberikan alat dan media hasil kegiatan pembelajaran kepada sekolah sebagai hasil akhir dari kegiatan.

\section{KESIMPULAN}

Dari kegiatan pengabdian masyarakat yang telah dilakukan oleh tim pengabdi maka dapat disimpulkan bahwa kegiatan pengabdian telah cukup tercapai terlihat bahwa peserta didik berantusias dalam melaksanakan segala kegiatan dalam kegiatan pembuatan tanaman hidroponik teknik vertikal. Kegiatan dilakukan agar menanamkan rasa cinta dan kepedulian untuk merawat dan menjaga lingkungan sekolah agar tercipta lingkungan asri dan nyaman.

\section{DAFTAR PUSTAKA}

[1] Mulyana, R. (2009). Penanaman etika lingkungan melalui sekolah perduli dan berbudaya lingkungan. Jurnal Tabularasa, 6(2), 175-180.

[2] Mulyana, R. (2009). Penanaman etika lingkungan melalui sekolah perduli dan berbudaya Mukminin, A. (2014). Strategi Pembentukan Karakter Peduli Lingkungan di Sekolah Adiwiyata Mandiri. Ta'dib, 19(02), 227-252.
[3] Mulyana, R. (2009). Penanaman etika lingkungan melalui sekolah perduli dan berbudaya Gunawan, Z. (2016). Pengembangan Program Adiwiyata dalam Mewujudkan Sekolah Peduli dan Berbudaya Lingkungan. Pedagogik; Jurnal Pendidikan, 3(2).

.[4] Sya'ban, M. F. (2014). Kepedulian Lingkungan Dengan Pembelajaran IPA Terintegrasi Kearifan Lokal. QUANTUM, 5(2).

[5] Roidah, I. S. (2015). Pemanfaatan lahan dengan menggunakan sistem hidroponik. Jurnal BONOROWO, 1(2), 43-49.

[6] Johnson, E. (2014). Hydroponic Gardening: Promoting Victory for School Nutrition. Journal of the Academy of Nutrition and Dietetics, 114(9), A56.

[7] Siswadi, Y. T. (2015). Pengaruh macam media terhadap pertumbuhan dan hasil selada (Lactuca sativa L.) hidroponik. Jurnal Agronomika, 9(3), 257-264.

[8] Widiastuti, R. (2015). Evaluasi Termal Dinding Bangunan dengan Vertikal Garden. Jurnal Penelitian dan Pengabdian kepada Masyarakat UNSIQ, 1(1).

[9] Roidah, I. S. (2015). Pemanfaatan lahan dengan menggunakan sistem hidroponik. Jurnal BONOROWO, 1(2), 43-49. 